\title{
PARENT COACHING DAN AKTIVITAS BERBASIS LAYAR SEBAGAI BENTUK SEDENTARY BEHAVIOUR PADA ANAK PRA SEKOLAH
}

\author{
Laviana Nita Ludyanti, Linda Ishariani \\ (Stikes Karya Husada Kediri, Soekarno Hatta 7 Kediri)
}

\begin{abstract}
Screen-based behavior which is part of sedentary behavior arises due to various facilities from the development of science and technology. This has various impacts on growth and development in children, so it is necessary to apply parent coaching. The purpose of this study was to determine the effect of parent coaching on sedentary behavior in pre-school children. This research uses quasy experimental design with a pre testpost test approach. The sample in this study were 45 respondents taken using the Purpossive Sampling Technique. This research was conducted at TK ABA III Pare Kediri. Researchers identified inactivity before and after the parent coaching intervention was given. This study uses a bivariate paired t test analysis. The results of the analysis showed a $p$ value of 0,000 which means that there is an influence between parent coaching on impaired behavior in preschool children.
\end{abstract}

Keywords: Parent Coaching, Screen Based Behavior, Pre-School Children

\begin{abstract}
Abstrak
Perilaku berbasis layar yang merupakan bagian dari perilaku kurang gerak (sedentary behaviour) muncul akibat adanya berbagai kemudahan dari perkembangan ilmu pengetahuan dan teknologi. Hal ini menimbulkan berbagai dampak terhadap pertumbuhan dan perkembangan pada anak, sehingga perlu diterapkan adanya parent coaching. Tujuan penelitian ini untuk mengetahui pengaruh parent coaching terhadap perilaku kurang gerak (sedentary behaviour) pada anak pra sekolah. Penelitian ini menggunakan desain quasy eksperimen dengan pendekatan pre tes post tes. Sampel dalam penelitian ini sebanyak 45 responden yang diambil dengan menggunakan Teknik Purpossive Sampling. Penelitian ini dilakukan di TK ABA III Pare Kediri. Peneliti mengidentifikasi perilaku kurang gerak sebelum dan sesudah diberikan intervensi parent coaching. Penelitian ini menggunakan analisa bivariat paired t test. Hasil analisa menunjukkan nilai $p$ value sebesar 0,000 yang berarti terdapat pengaruh antara parent coaching terhadap perilaku kurang gerak pada anak pra sekolah.
\end{abstract}

Kata Kunci : Parent Coaching; Perilaku Berbasis Layar; Anak Pra Sekolah

\section{PENDAHULUAN}

Kemajuan teknologi pada masa globalisasi saat ini sangat pesat terutama perkembangan teknologi berbasis layar seperti televisi, komputer, gadget dan internet. Perkembangan tehnologi ini dapat berpengaruh pada kehidupan anak-anak terutama pada anak usia prasekolah. Usia prasekolah dimana fase pertumbuhan dan perkembangan anak berlangsung dengan cepat. Anak-anak sangat menyukai bermain dan terbiasa dengan gadget atau laptop daripada bermain bersama teman-temannya. Anak-anak sibuk bermain dengan gadget atau laptopnya selama berjam-jam tanpa ada aktifitas fisik yang dilakukan ${ }^{1}$. Hal ini mengakibatkan anak memiliki perilaku malas 
bergerak (sedentary behaviour). Penggunaan teknologi berbasis layar dan interaksinya dengan anak akan mengurangi aktivitas gerak anak. Survei yang dilakukan oleh Kementerian Informasi dan Unicef tahun 2014 pengguna gadget pada usia anak dan remaja di Indonesia dalam kategori tinggi (79,5\%). Berdasarkan penelitian Heni dalam Arundhana 2013, mengemukakan bahwa penggunaan smartphone pada anak usia prasekolah dalam kategori sering $(72,7 \%)^{2}$.

Hasil penelitian Valerie, et all menunjukkan gaya hidup menetap juga terjadi di awal tahapan tumbuh kembang yaitu usia 0-5 tahun. Anak-anak di tahun-tahun awal menghabiskan $73 \%-84 \%$ dari waktu bangun mereka menunjukkan perilaku kurang gerak. Sebagian besar anak-anak di tahun-tahun awal menghabiskan lebih dari 1 jam per hari untuk di depan layar (screen time) dan melakukan kegiatan berbasis layar sebelum usia 2 tahun ${ }^{3,4}$. Sedentary behaviour menimbulkan efek negatif terhadap kesehatan, sehingga menjadikannya sebagai isu penting dalam kesehatan masyarakat. Sedentary behaviour merupakan sekelompok perilaku yang terjadi saat duduk atau berbaring yang membutuhkan pengeluaran energi yang sangat rendah, seperti duduk atau berbaring sambil menonton televisi, bermain game elektronik, membaca, dan lain sebagainya. Dampak yang dapat ditimbulkan dari sedentary behaviour diantaranya adalah gangguan kardiometabolik, gangguan respirasi (asma), gangguan psikososial (cemas, depresi, harga diri rendah) dan termasuk juga gangguan pertumbuhan dan perkembangan ${ }^{4,5,6}$.

Masa pra sekolah merupakan masa yang sangat peka terhadap lingkungan, masa sangat pendek dan tidak dapat diulang lagi sehingga masa ini disebut sebagai masa keemasan (golden period), jendela kesempatan (window of opportunity), dan juga sebagai masa kritis (critical periode) ${ }^{7}$. Anak yang lebih banyak mengalami sedentary behavior,akan lebih banyak waktu digunakan untuk bermain sendiri, kurang bergerak dan berinteraksi dengan lingkungan luar. Hal ini tentunya juga akan berpengaruh terhadap perilaku anak baik secara individu maupun ke orang lain. Anak akan cenderung kurang mandiri, lebih emosi, agresif, sulit berkomunikasi dan bergaul dengan teman lain,perilaku manja, perilaku merusak dan sulit berkonsentrasi ${ }^{8,9,10,11,12}$. Perilaku sedentary pada anak sendiri dipengaruhi oleh beberapa faktor seperti status ekonomi, pendidikan orang tua dan lingkungan. Peran orangtua sangat penting untuk mencegah perilaku sedentary. Salah satunya melalui parent coaching. Parents coaching sangat membantu orangtua dalam mengarahkan dan mengembangkan pertumbuhan dan perkembangan anak. Orang tua dalam proses dapat mengetahui perkembangan anaksaat ini, mengetahui tujuan yang ingin diraih oleh anak, dan menjadi partner untuk mencari jalan dalam mengoptimalkan pertumbuhan dan perkembangan anak. Selain itu juga akan meningkatkan interaksi antara orang tua dan anak ${ }^{11 .}$ 
Tujuan penelitian ini adalah untuk mengetahui pengaruh parent's coachingterhadap perilaku kurang gerak (Sedentary Behaviour) anak usia pra sekolah.Tujuan khusus dari penelitian adalah untuk mengidentifikasi parent coaching dan perilaku kurang gerak (sedentary behaviour) anak usia prasekolah serta menganalisa pengaruhnya.

\section{METODE PENELITIAN}

Desain pada penelitian ini adalah quasy eksperimen dengan pendekatan pre test post test ${ }^{13}$ Penelitian ini dilakukan untuk mengidentifikasi perilaku kurang gerak (sedentary behaviour) pada anak pra sekolah.Penelitian ini dilakukan di TK ABA III Pare Kediri. Populasi pada penelitian ini sebanyak 45 anak.Jumlah responden dalam penelitian ini adalah 45 responden sesuai dengan kriteria inklusi. Teknik sampling dalam penelitian ini adalah purpossive sampling, dengan kriteria inklusi yaitu ibu bersedia menjadi responden, kooperatif, ibu dengan anak usia 4-6 tahun.

Sebelum penelitian, responden diberikan informed consent. Selanjutnya responden diberikan kuesioner perilaku kurang gerak dan diambil data pre test. Peneliti memberikan intervensi parent coaching melalui modul Parent coaching yang telah ber ISBN. Intervensi tersebut terbagi dalam 4 kegiatan yang meliputi kegiatan I (menggali pemahaman peserta), Kegiatan II (Diskusi kelompok), kegiatan III (refleksi), kegiatan IV (Penguatan). Penelitian dilakukan oleh peneliti selama 1 bulan. Peneliti mengidentifikasi perilaku kurang gerak setelah dilakukan intervensi. Pengumpulan data dilakukan dengan memberikan kuesioner post test.Selanjutnya hasil pre test dan post test dianalisa. Analisa data pada penelitian ini dengan menggunakan paired $t$ test.

\section{HASIL PENELITIAN}

Pada penelitian ini bertujuan untuk mengidentifikasi perilaku kurang gerak pada anak usia 4-6 tahun sebelum dan sesudah diberikan intervensi parent coaching. Selanjutnya dilakukan analisa pengaruh parent coaching terhadap perilaku kurang gerak pada anak usia 4-6 tahun. Berikut ini adalah tabel karekteristik responden berdasarkan umur, pendidikan, pekerjaan orang tua, jenis kelamin anak, usia anak dan jumlah saudara kandung anak. 


\begin{tabular}{clcc}
$\begin{array}{l}\text { Tabel 1. Distribusi Frekuensi Responden Berdasarkan Umur, Pendidikan, dan } \\
\text { Pekerjaan Orang Tua }\end{array}$ \\
\hline \multicolumn{1}{c}{ Variabel } & \multicolumn{1}{c}{ Kategori } & Frekuensi & Prosentase (\%) \\
\hline Usia Ibu & $20-30$ tahun & 14 & 31,11 \\
& $31-40$ tahun & 24 & 53,33 \\
& $>40$ tahun & 7 & 15,56 \\
\hline Pendidikan Ibu & SD & 2 & 4,44 \\
& SMP & 4 & 8,89 \\
& SMA & 29 & 64,44 \\
& PT & 10 & 22,22 \\
\hline Pekerjaan Ibu & IRT & 28 & 62,22 \\
& Wiraswasta & 4 & 8,89 \\
& Swasta & 6 & 13,33 \\
& Guru & 5 & 11,11 \\
& Tani & 1 & 2,22 \\
& Perawat & 1 & 2,22 \\
\hline Jenis Kelamin Anak & Laki-laki & 21 & 46,67 \\
& Perempuan & 24 & 53,33 \\
\hline Usia Anak & 4 tahun & 5 & 11,11 \\
& 5 tahun & 21 & 46,67 \\
& 6 tahun & 19 & 42,22 \\
\hline Jumlah saudara kandung & Tidak punya & 8 & 17,78 \\
& 1 & 20 & 44,44 \\
& 2 & 11 & 24,44 \\
& 3 & 5 & 11,11 \\
& 4 & 1 & 2,22 \\
\hline
\end{tabular}

Tabel 1 menjelaskan bahwa responden sebagian besar berusia 30-40 tahun sebanyak $53,33 \%$, dengan usia paling muda adalah 22 tahun dan paling tua 48 tahun. Pendidikan ibu paling banyak adalah SMA, ditunjukkan sebesar 64,44\%. Pekerjaan responden paling banyak adalah sebagai ibu rumah tangga (IRT) sebesar 62,22 \%. Sedangkan jenis kelamin anak lebih banyak perempuan sebesar $53,33 \%$. Usia anak pra sekolah yang paling banyak berusia 5 tahun sebesar 46,67\%. Jumlah saudara kandung yang paling banyak sebanyak 1 saudara yang ditunjukkan dengan prosentase sebesar $44,44 \%$. Hasil uji statistik pada penelitian ini dapat dilihat pada tabel berikut ini.

Tabel 2. Hasil Uji statistik

\begin{tabular}{lccccc}
\hline & N & Mean & Std.Deviation & $\begin{array}{c}\text { Sig.(2 } \\
\text { tailed) }\end{array}$ \\
\hline Pre test & 45 & 5,4 & 1,8841 & \\
\hline Post test & 45 & 3,11 & 1,29373 & \\
\hline Paired t test & Pretest-post test & 45 & 2.28889 & 2.02958 & .000 \\
\hline
\end{tabular}

Tabel 2, menjelaskan bahwa rata-rata perilaku kurang gerak pada anak pra sekolah sebelum diberikan parent coaching adalah 5,4. Sedangkan perilaku kurang gerak setelah 
diberikan parent coaching sebesar 3,11. Dari hasil uji statistik paired T test menunjukkan nilai $\mathrm{p}$ sebesar 0,000 yang artinya terdapat pengaruh parent coaching terhadap perilaku sedentari (sedentary behaviour) pada anak usia pra sekolah.

\section{PEMBAHASAN}

Monitoring aktivitas dan pembatasan perilaku kurang gerak (sedentary behaviour) sangat penting dilakukan oleh orang tua. Hal ini dilakukan untuk optimalisasi pertumbuhan dan perkembangan pada anak, terutama pada usia pra sekolah. Berdasarkan penelitian ini didapatkan data bahwa paling banyak adalah anak usia 5 tahun. Usia pra sekolah merupakan fase keemasan pada pertumbuhan dan perkembangan anak, sehingga diperlukan perhatian yang lebih agar pertumbuhan dan perkembangannya dapat tercapai secara optimal ${ }^{14,15,16}$. Salah satunya dengan memperhatikan aktivitas yang dilakukan sehari-hari agar tidak terjadi perilaku kurang gerak. Pada anak usia pra sekolah, berdasarkan penelitian didapatkan perilaku kurang gerak yang banyak dilakukan adalah perilaku berbasis layar atau screen time. Perilaku kurang gerak pada anak usia sekolah dijelaskan dengan aktivitas yang membutuhkan pengeluaran energi rendah yaitu 1,0 hingga 1,5 ekuivalen metabolik (MET) atau dapat diidentifikasi dengan aktivitas istirahat. Beberapa perilaku yang termasuk perilaku kurang gerak seperti duduk untuk berbagai tujuan (misalnya kerja, perjalanan), dan aktivitas berbasis layar seperti penggunaan komputer, permainan elektronik, dan menonton televisi ${ }^{8,17}$.

Pekerjaan orang tua dan pengasuhan yang diberikan, menjadi salah satufaktor yang mempengaruhiperilakukuranggerak pada anak ${ }^{18}$. Berdasarkan penelitian, pekerjaan ibu yang paling banyak sebagai pekerja swasta atau wanita karir. Orang tua cenderung membiarkan anak untuk bermain sendiri supaya anak lebih tenang. Hal ini menjadi sebuah kesempatan bagi anak untuk lebih memilih bermain gadget, menonton televisi atau bermain dengan media berbasis layar lainnya. Selain itu, orang tua terkadang juga mempercayakan pengasuhan anaknya kepada pengasuh atau kepada nenek, sehingga kontrol terhadap aktivitas anak juga cenderung kurang. Oleh sebab itu anak lebih banyak melakukan aktivitas yang kurang mengeluarkan energi dan bahkan justru memilih aktivitas yang berbasis layar. Oleh sebab itu anak lebih banyak melakukan aktivitas yang kurang mengeluarkan energi dan bahkan justru memilih aktivitas yang berbasis layar.

Hal yang sama juga ditemukan pada penelitian Williams, et all, bahwa pada anak toddler dan pra sekolah, lebih dari setengah $52,81 \%$ dilaporkan lebih banyak kegiatan duduk daripada melakukan aktivitas lainnya yang membutuhkan banyak energi ${ }^{17}$.Kegiatan menonton televisi dan bermain video game sambil duduk menurunkan pengeluaran energi daripada saat anak bermain di luar ruangan seperti bermain bola, bersepeda, berenang atau 
kegiatan lainnya. Waktu layar (screen time) harian anak-anak bervariasi dari 1,7 jam/ hari pada orang tua dengan status sosial ekonomi tinggi hingga 2,4 di keluarga dengan status sosial ekonomi yang rendah. Media screen time yang tersedia di kamar tidur terkait dengan waktu layar menunjukkan adanya hubungan waktu layar dengan status sosial ekonomi orang tua ${ }^{19}$.

Hal ini tidak sesuai dengan rekomendasi dari Australian 24-Hour Movement Guidelines forthe Early Years (birth to 5 years)yang menyatakan bahwaaktivitas fisik pada anak pra sekolah setidaknya 180 menit dihabiskan dalam berbagai aktivitas fisik, yaitu 60 menit adalah bermain energik, bergerak sepanjang hari. Aktivitas fisik memberi peran penting dalam pengeluaran energi karena $20-50 \%$ energi dikeluarkan dengan aktivitas fisik. Kurang aktivitas fisik menyebabkan kelebihan energi akan disimpan dalam bentuk jaringan lemak $^{5,6,20}$. Oleh sebab itu, peran orang tua sangat penting untuk mengarahkan kegiatan dan mengoptimalkan pertumbuhan dan perkembangan anak. Hal ini dapat dilakukan melalui kegiatan parent coaching.Bimbingan yang diberikan kepada anak membantu dalam meningkatkan kemampuan untuk memahami diri sendiri (self understanding), kemampuan menerima dirinya sendiri (Self Acceptance), kemampuan untuk mengarahkan dirinya sendiri (Self direction) dan kemampuan untuk merealisasikan dirinya sendiri (Self realization) sesuai potensi atau kemampuannya dalam menyesuaikan diri dan lingkungannya ${ }^{21,22}$. Parent coaching dapat diberikan melalui nasehat, keteladanan, pembiasaan dan pengawasan ${ }^{16}$.

Pada anak pra sekolah yang diberikan parent coaching menunjukkan adanya perbaikan terhadap sedentary behaviour. Data anak di TK ABA III yang diperoleh melalui responden menunjukkan kecenderungan mengalami perilaku kurang geraksebelum diberikan intervensi berupa parent coaching selama satu bulan. Rata-rata perilaku kurang gerak pada anak pra sekolah menunjukkan skor 5,4. Akan tetapi setelah diberikan parent coaching, perilaku kurang gerak pada anak mengalami penurunan ratarata sebesar 3.1. Penurunan paling banyak didapatkan pada aktivitas screen time. Dari analisis uji statistik menunjukkkan $p$ value $<0,05$. Hal ini menunjukkan bahwa pemberian intervensi parent coaching efektif untuk diberikan ke orangtua dengan anak yang mengalami perilaku kurang gerak terutama aktivitas screen time atau aktivitas berbasis layar. Adanya penurunan perilaku kurang gerak pada anak pra sekolah akan menurunkan resiko yang timbul dari perilaku tersebut baik secara fisik maupun psikologis sehingga tumbuh kembang dapat tercapai secara optimal.Perkembangan anak baik motorik, sensorik, kognitif dan psikososial dapat berkembang dengan baik dan dapat mengurangi resiko kesehatan pada anak usia prasekolah ${ }^{3}$. 


\section{SIMPULAN DAN SARAN}

Perilaku kurang gerak pada anak pra sekolah yang lebih banyak muncul pada responden adalah aktivitas berbasis layar. Pemberian parent coaching berpengaruh terhadap perilaku kurang gerak pada anak usia pra sekolah yang ditunjukkan dengan adanya penurunan skor perilaku kurang gerak terutama menurunnya aktivitas berbasis layar pada anak. Disarankan orang tua hendaknya menerapkan parent coaching dalam kehidupan sehari-hari sehingga dampak sedentary behaviour pada anak pra sekolah terhadap pertumbuhan dan perkembangannya dapat diminimalisasi. Adanya pembatasan aktivitas berbasis layar diperlukan juga pada anak sehingga akan terhindar dampak buruk dari perilaku kurang gerak.

\section{DAFTAR PUSTAKA}

1. Khaironi M. Perkembangan anak usia dini. J Golden Age Hamzanwadi Univ. 2018;

2. Arundhana $\mathrm{Al}$, Hadi $\mathrm{H}$, Julia $\mathrm{M}$. Perilaku sedentari sebagai faktor risiko kejadian obesitas pada anak sekolah dasar di Kota Yogyakarta dan Kabupaten Bantul. J Gizi dan Diet Indones (Indonesian J Nutr Diet. 2016;

3. Carson V, Kuzik N, Hunter S, Wiebe SA, Spence JC, Friedman A, et al. Systematic review of sedentary behavior and cognitive development in early childhood. Preventive Medicine. 2015.

4. LeBlanc AG, Spence JC, Carson V, Gorber SC, Dillman C, Janssen I, et al. Systematic review of sedentary behaviour and health indicators in the early years (aged 0-4 years). Applied Physiology, Nutrition and Metabolism. 2012.

5. Owen N, Sparling PB, Healy GN, Dunstan DW, Matthews CE. Sedentary behavior: Emerging evidence for a new health risk. Mayo Clinic Proceedings. 2010.

6. Pearson N, Salmon J, Campbell K, Crawford D, Timperio A. Tracking of children's bodymass index, television viewing and dietary intake over five-years. Prev Med (Baltim). 2011;

7. Hurlock E. Perkembangan Anak Edisi Keenam Jilid I. Jakarta. Penerbit Erlangga. 2014.

8. Bingham DD, Costa S, Hinkley T, Shire KA, Clemes SA, Barber SE. Physical Activity During the Early Years: A Systematic Review of Correlates and Determinants. American Journal of Preventive Medicine. 2016.

9. Cliff DP, Hesketh KD, Vella SA, Hinkley T, Tsiros MD, Ridgers ND, et al. Objectively measured sedentary behaviour and health and development in children and adolescents: Systematic review and meta-analysis. Obes Rev. 2016;

10. Hinkley T, Teychenne M, Downing KL, Ball K, Salmon J, Hesketh KD. Early childhood physical activity, sedentary behaviors and psychosocial well-being: A systematic review. Preventive Medicine. 2014.

11. Suryana D. PENDIDIKAN ANAK USIA DINI Stimulasi dan Aspek Perkembangan Anak. 
Kencana. 2016;

12. Teychenne M, Costigan SA, Parker K. The association between sedentary behaviour and risk of anxiety: A systematic review Health behavior, health promotion and society. BMC Public Health. 2015.

13. Nursalam. Metodologi Penelitian IImu Keperawatan:Pendekatan Praktis. Salemba Medika. 2015.

14. Hildayani R, Sugianto, M. T, Arigan R, Handayani E. Psikologi Perkembangan Anak. Universitas Terbuka. 2014.

15. Papalia DE. Human Development (Psikologi Perkembangan). In: Cetakan ke-1. 2015.

16. Cahyaningrum ES, Sudaryanti S, Purwanto NA. PENGEMBANGAN NILAI-NILAI KARAKTER ANAK USIA DINI MELALUI PEMBIASAAN DAN KETELADANAN. J Pendidik Anak. 2017;

17. Byrd-Williams CE, Dooley EE, Thi CA, Browning C, Hoelscher DM. Physical activity, screen time, and outdoor learning environment practices and policy implementation: A cross sectional study of Texas child care centers. BMC Public Health. 2019;

18. Indriati R, Puspitasari UP. HUBUNGAN TINGKAT PENDIDIKAN DAN POLA ASUH ORANG TUA DENGAN PERKEMBANGAN PSIKOSOSIAL ANAK PRA SEKOLAH DI TK AL-ABIDIN BANYUANYAR SURAKARTA. Kosala J IImu Kesehat. 2016;

19. Tandon PS, Zhou C, Sallis JF, Cain KL, Frank LD, Saelens BE. Home environment relationships with children's physical activity, sedentary time, and screen time by socioeconomic status. Int J Behav Nutr Phys Act. 2012;

20. de Gouw L, Klepp KI, Vignerová J, Lien N, Steenhuis I hm, Wind M. Associations between diet and (in)activity behaviours with overweight and obesity among 10-18year-old Czech Republic adolescents. Public Health Nutr. 2010;

21. Kamaluddin H. Bimbingan dan Konseling Sekolah. J Pendidik dan Kebud. 2011;

22. Moersintowati NB, Sularyo TS, Soetjiningsih HS, Ranuh IGNG. Tumbuh Kembang Anak dan Remaja. Nancy Pardede. Jakarta: CV Sagung Seto. 2010. 